\title{
A Conceptual Knowledge Model for Research of Critical Energy Infrastructures
}

\author{
Tatiana Vorozhtsova \\ Melentiev Energy Systems Institute of Siberian Branch of \\ the Russian Academy of Sciences \\ Irkutsk, Russia \\ tnn@isem.irk.ru
}

\author{
Natalia Pyatkova \\ Melentiev Energy Systems Institute of Siberian Branch of \\ the Russian Academy of Sciences \\ Irkutsk, Russia \\ nata@isem.irk.ru
}

\begin{abstract}
The article proposes a conceptual model of knowledge for the study of the fuel and energy complex as a critical infrastructure. A system of interrelated ontological models reflecting the basic concepts of the subject area and their relationship is proposing as a conceptual model. The structure of the fuel and energy complex objects, the tasks of research from the standpoint of energy security, the models used for research and the corresponding information base are considered. Quantitative information is presented by technical and economic characteristics of energy facilities, reporting data and research results on the development of the fuel and energy complex. The developed system of ontologies is using to structure and integrate knowledge in the study of critical energy infrastructures.
\end{abstract}

Keywords- critical infrastructure, energy security, fuel and energy complex, ontology, meta-ontology, conceptual model, knowledge modeling, fractal model.

\section{INTRODUCTION}

At present, studies of critical infrastructures are becoming more and more relevant. Abroad, studies of critical infrastructures began in the $90 \mathrm{~s}$ of the last century, various interpretations of the term "critical infrastructure" were proposed $[1,2]$, research centers were established.

Critical is infrastructure, elements of which are of particular importance for the state and society, the breakdown or limitation of which would lead to long supply interruptions, serious public safety violations or other dramatic consequences [3]. Critical infrastructure includes facilities, networks, services and systems whose failure will affect the health, safety and well-being of citizens. In accordance with this definition, the Fuel and Energy Complex (FEC), which is an interconnected infrastructure consisting of separate energy systems can be categorized as critical infrastructures.

The Federal law "On the safety of fuel and energy facilities" [4] defines critical facilities of the fuel and energy complex. These include objects, the violation or termination of which will lead to the loss of control of the economy of the Russian Federation, the subject of the Russian Federation or the administrativeterritorial unit, its irreversible negative change (destruction) or a significant decrease in the safety of life of the population.
At the Melentiev Energy Systems Institute of Siberian Branch of the Russian Academy of Sciences (MESI SB RAS) the study of the fuel and energy complex as a critical infrastructure is one of the important areas of research of reliable energy supply to consumers.

\section{FUEL AND ENERGY COMPLEX AS CRITICAL INFRASTRUCTURE}

This law gives the following definitions of the subject area.

Fuel and energy complex objects are electric power, oil-producing, oil-refining, petrochemical, gas, coal, shale and peat industries, as well as the objects of oil, heat and gas supply facilities.

Linear objects of fuel and energy complex are electric networks, main gas pipelines, oil pipelines and oil product pipelines designed to provide transmission of electric energy, transportation of gas, oil and oil products.

The critical elements of the fuel and energy facility include potentially dangerous elements (areas), the Commission of an act of unlawful interference in respect of which will lead to the termination of the normal functioning of the fuel and energy facility, its damage or an accident at the fuel and energy facility.

Potentially hazardous fuel and energy facilities are facilities, sites, or structural elements of facilities where radioactive, explosive, fire-hazardous and dangerous chemical and biological substances are used, produced, processed, stored, operated, transported or destroyed, as well as hydraulic and other facilities, accidents on which can lead to emergency situations with dangerous socio-economic consequences.

Protected objects of fuel and energy complex are buildings and structures as well as adjacent territories and water areas within the established boundaries.

These definitions are basic in the description of the subject area.

The law also provides for the categorization of fuel and energy facilities, taking into account the degree of potential danger of an act of unlawful interference and its possible consequences. The following factors are taken into account: 
- is the facility a critical facility for fuel and energy infrastructure and life support

- extent of possible socio-economic consequences of accidents

- existence of critical elements of the fuel and energy complex

- existence of potentially hazardous areas of the fuel and energy complex

- existence of vulnerabilities at the fuel and energy complex.

The main purpose of ensuring the safety of fuel and energy facilities is their stable and safe functioning, protection of the interests of the individual, society and the state from acts of unlawful interference.

\section{RESEARCH TASKS}

MESI SB RAS carries out studies of critical infrastructures from the standpoint of energy security. Energy security of the country and its regions means a balance of energy supply and demand in critical or emergency situations [5]. Figure 1 presents a scheme reflecting the interrelationships of the basic characteristics taken into account when modeling the functioning of fuel and energy complex facilities.

This requires taking into account many characteristics of energy facilities, as well as the territorial and production structure. One of the main objectives of the research is to identify key objects (or a combination of them) that may have the most negative impact on the industry, key resource or the entire infrastructure. It is necessary to assess the effects of such exposure and develop mechanisms to reduce such risks. The following tasks are solving:

- The formation of possible threats

- Development of potential threat scenarios

- Vulnerability analysis

- Assessment of negative impacts

- Development of risk reduction mechanisms

- Forecasting of the state of energy systems

- Assessment of the energy systems operation

Studies of critical infrastructures are performing using computational experiments. The problems of forecasting, functioning and assessment of energy systems with regard to possible emergency situations are solving, as well as the problem of choosing measures to reduce their negative impact.

To solve these problems, the system of economic and mathematical models of functioning of energy systems and fuel and energy complex as a whole is used [6]. The territorial-production models used reflect the technological cycle of energy resources conversion, imitate the work of key industry objects in the given operating conditions. In this case, the possible States of energy facilities in emergency situations are simulated.

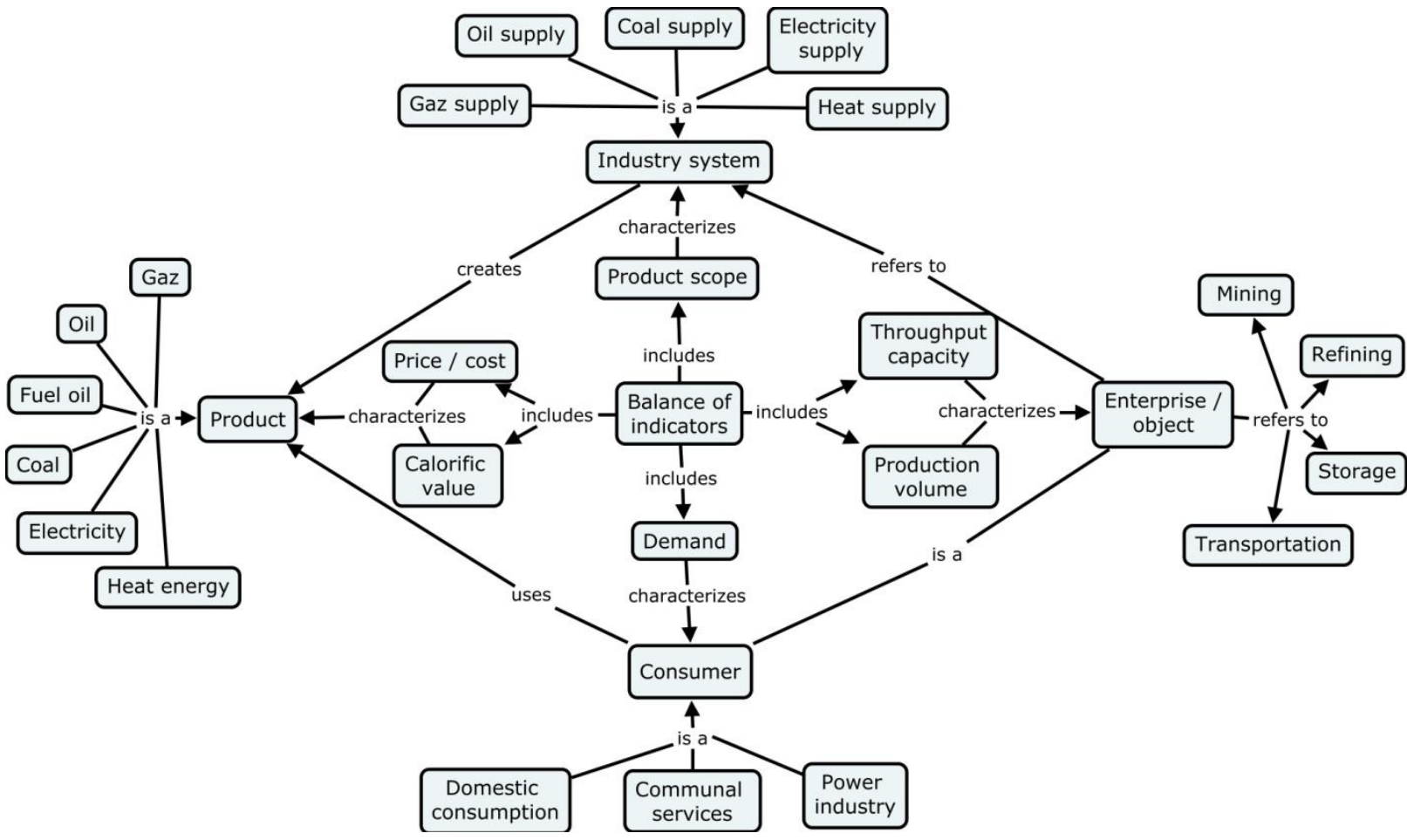

Fig. 1. Balance of indicators 


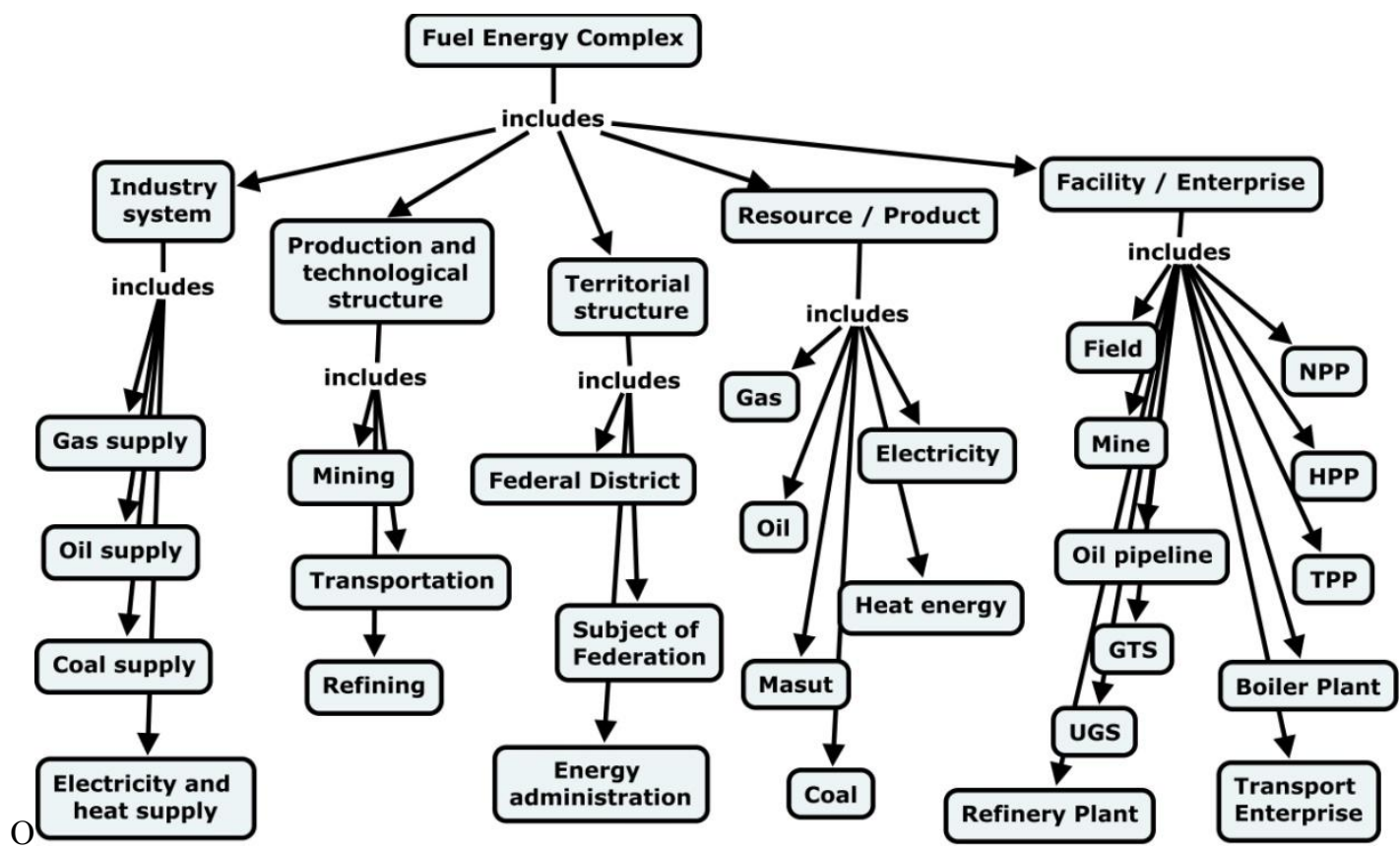

Fig. 2. Metaontology of Fuel and Energy Complex

\section{KNOWLEDGE FOR RESEARCH ON CRITICAL INFRASTRUCTURES}

Fairly complex information is required for research, including:

- Technical and economic characteristics of energy facilities

- Reporting data on the state of energy systems

- Object location

- Relations between objects

- The importance of the object for the interrelated stages of the production process

- Interaction with other infrastructure elements

The results of fuel and energy sector development studies and other indicators characterizing the cycle of energy resources transformation are taking into account The models used take into account the territorial, sectoral, temporal division and a variety of fuel and energy resources, facilities and territorial entities. Objects are described by technical and economic characteristics and resource transformation processes occurring in them. The models used take into account inter-branch communications, the state of the fuel and energy complex and energy systems in emergency situations and reveal limitations that negatively affect the reliable supply of consumers with fuel and energy. [7].

\section{CONCEPTUAL MODEL OF THE KNOWLEDGE BASE}

To systematize and structure the complex information component, it is proposed to develop a knowledge base that includes not only quantitative indicators of functioning, which, as a rule, accumulate in databases, but also the relationship of objects of this subject area.

Conceptual models use to build knowledge-based systems. Conceptual modeling is a formal description of the aspects of the subject area under study for the purpose of understanding and communication [8-11].

The conceptual model of the knowledge base is a system description of the knowledge used, consisting of a set of interrelated concepts, their properties and characteristics, with the classification of these concepts by types, situations and characteristics. It is proposed the ontological model in the form of a system of ontologies united by meta-ontology as a conceptual model $[12,13]$.

When developing an ontological model, a fractal approach is used [14], which allows providing the necessary information about the domain in the form of non-intersecting layers that unite objects of the same type. In addition, each information layer can be stratified and detailed.

Metaontology includes basic concepts, for example, system, industry, object, resource, and others. For the subject domain under consideration, the following metaontology is proposed (Fig. 2), reflecting the concepts used in the study and modeling of the fuel and energy complex.

Each of the elements is not only detailed at the next level of consideration, but also has interrelations with other concepts at its own level. For example, Figure 3 shows the connections of the Resource concept with other concepts of metaontology.

In turn, the extractive industries include various deposits of resources. Electricity and heat supply respectively include types of power plants and boilers. 


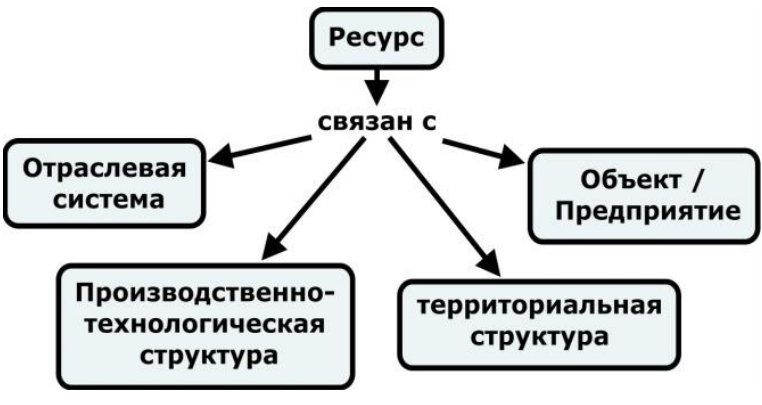

Fig. 3. Relationships of the Resource Concept

The concept of "Production and technological structure" details the stages of the production process the extraction, transportation, processing and storage of energy resources.

The concept «Territorial structure» is taken into account in research includes federal districts, subjects of the federation and regional energy associations. Similarly, ontologies reflect types of energy produced and consumed, types of energy enterprises.

The ontologies of each next level detail the sections of the subject area under study, for example, research tasks, fuel and energy complex models, resource conversion cycle, etc.

It is proposed to use ontologies of the lower level containing a description of the technical and economic characteristics of the objects to form databases containing the required quantitative information. Ontological models are used to develop infological data models on the basis of which databases are designed.

\section{CONCLUSION}

The proposed conceptual model of knowledge for the study of critical infrastructures in the energy sector is a system of interconnected ontologies presented at the top level by the meta-methodology of fuel and energy complex research.

Metaontology unites several layers of ontologies reflecting different aspects of knowledge taken into account when modeling and carrying out research, namely, the industry and production structure, territorial links, the structure of resources and energy objects.

At a more detailed level, ontologies include a description of energy systems, their state and characteristics, research tasks and models, possible threats, scenarios for the functioning of objects, software, etc. This information is presented in graphical form and can be converted into formats suitable for automated processing.

The proposed conceptual knowledge model is used to structure and integrate knowledge in the study of critical energy infrastructures. The developed system of ontologies provides for the exchange of knowledge and interaction of researchers in this subject area.

\section{ACKNOWLEDGMENT}

The work is carried out in the framework of the project on state assignment of MESI SB RAS AAAAA17-117030310444-2.

\section{REFERENCES}

[1] S. Rinaldi, J. Peerenboom and T. Kelly, Identifying, understanding and analyzing critical infrastructure interdependencies, IEEE Control Systems, vol. 21(6), pp. 1125, 2001.

[2] Keating C., Rogers R., Dryer D., Sousa-Poza A. and other.System of Systems Engineering Engineering Management Journal, 2003.Vol. 15, № 3 (2003).

[3] Protection of critical infrastructure Concept of basic protection measures Recommendations for enterprises [Zashchita kriticheskoy infrastruktury Kontseptsiya osnovnykh mer zashchity Rekomendatsii dlya predpriyatiy]. Available at: https://docplayer.ru/26181451-Zashchitakriticheskoy-infrastruktury-koncepciya-osnovnyh-merzashchity.html (accessed 10.02.2019) (in Russian).

[4] Federal law №. 256-FZ "On the safety of fuel and energy facilities" = [Federal'nyy zakon № 256-FZ «O bezopasnosti ob"yektov toplivno-energeticheskogo kompleksa»]. Available at: http://www.garant.ru/products/ipo/prime/doc/12088188 (accessed 18.02.2019) (in Russian).

[5] Energy security of Russia: problems and solutions / $\mathrm{N}$. Pyatkova [et al.], resp. N.I. Voropai, M.B. Cheltsov; RAS, SB., Melentye Energy Systems Institute - Novosibirsk: Publishing house of SB RAS, 2011. - 198 p. [Energeticheskaya bezopasnost' Rossii: problemy i puti resheniya] / N.I. Pyatkova [i dr.], otv. red. N.I. Voropay, M.B. Chel'tsov; Ros. Akad. Nauk, Sib. otd-niye, In-t sistem energetiki im. L.A. Melent'yeva. - Novosibirsk: Izd-vo SO RAN], 2011. - 198 p.(in Russian)

[6] Beresneva N.M., Pyatkova N.I. Features of modeling the functioning of critical energy infrastructure, taking into account energy security / Energy policy. - 2018. - № 1. - Pp. 3-12. [Beresneva N.M., Pyatkova N.I. Osobennosti modelirovaniya funktsionirovaniya kriticheskikh infrastruktur energetiki s uchetom energeticheskoy bezopasnosti / Energeticheskaya politika. - 2018. - № 1. - P. 3-12]. .(in Russian)

[7] Beresneva N.M., Edelev A.V., Pyatkova N.I. Research of critical energy infrastructures from the standpoint of energy security / Methodological issues of research of reliability of large energy systems: Vol. 68. Research and ensuring the reliability of energy systems / Resp. N. I. Voropai - MESI SB RAS, 2017. 93-102. [Beresneva N.M., Yedelev A.V., Pyatkova N.I. Issledovaniye kriticheskikh infrastruktur energetiki $\mathrm{s}$ pozitsiy energeticheskoy bezopasnosti/Metodicheskiye voprosy issledovaniya nadezhnosti bol'shikh sistem energetiki: Vyp. 68. Issledovaniye i obespecheniye nadezhnosti sistem energetiki/Otv. red. N.I. Voropay - ISEM SO RAN,2017 г. P. 93-102] (in Russian).

[8] Tatomir A., McDermott C., Bensabat J., Class H., Edlmann K., Taherdangkoo R. and Sauter M. 2018. Conceptual model development using a generic Features, Events, and Processes (FEP) database for assessing the potential impact of hydraulic fracturing on groundwater aquifers. Adv. Geosci., 45, 185192, Available at: https://doi.org/10.5194/adgeo-45-185-2018. (accessed 12.02.2019)

[9] Sokolowski, John A.; Banks, Catherine M., eds. (2010). Modeling and Simulation Fundamentals: Theoretical Underpinnings and Practical Domains. Hoboken, NJ: John Wiley \& Sons. doi:10.1002/9780470590621. ISBN 9780470486740.

[10] Robinson S (2008). Conceptual modelling for simulation Part I: Definition and requirements. Journal of the Operational Research Society 59 (3): 278-290. 
[11] Roger J Brooks, Wang Wang. Conceptual modelling and the project process in real simulation projects: a survey of simulation modelers / Journal of the Operational Research Society. Vol 66, Issue 10, pp 1669-1685. Available at: https://link.springer.com/article/10.1057\%2Fjors.2014.128 (accessed 8.02.2019)

[12] Bukhanovsky A.V., Nechaev Y.I. Metaontology research designing of sea dynamic objects / Ontology design. - 2012. №. 1. - Pp. 53-64. [Bukhanovskiy A.V., Nechayev YU.I. Metaontologiya issledovatel'skogo proyektirovaniya morskikh dinamicheskikh ob"yektov / Ontologiya proyektirovaniya. - 2012. № 1. - P. 53-64].(in russian).

[13] Hofweber, Thomas (Aug 30, 2011). Edward N. Zalta, ed. "Logic and Ontology: Different conceptions of ontology". The Stanford Encyclopedia of Philosophy (Spring 2013 Edition). Available https://plato.stanford.edu/archives/spr2013/entries/logicontology/\#DifConOnt (accessed 7.02.2019).

[14] Massel L. V. Fractal approach to knowledge structuring and examples of its application / L. V. Massel / Ontology of design. - 2016. №2(20). - Pp. 149-161. [Massel' L.V. Fraktal'nyy podkhod $\mathrm{k}$ strukturirovaniyu znaniy i primery yego primeneniya / L.V. Massel' / Ontologiya proyektirovaniya. - 2016. №2(20). - P. 149-161]. DOI:10.18267/2223-9537-2016-6-2-149-161. (in russian). 